\title{
Variation in aboveground biomass and necromass of two invasive species in the Atlantic rainforest, Southeast Brazil
}

\author{
Rita Cássia Quitete Portela ${ }^{1}$, Dalva Maria Silva Matos ${ }^{2,4}$, Ludmila Pugliese de Siqueira ${ }^{1}$, \\ Maria Isabel Guedes Braz ${ }^{1}$, Leonardo Silva-Lima ${ }^{1}$ and Robert Hunter Marrs ${ }^{3}$
}

Received: April 4, 2008. Accepted: October 23, 2008

\begin{abstract}
RESUMO - (Variação da biomassa e necromassa aérea de duas espécies invasoras na Floresta Atlântica, sudeste do Brasil). Este trabalho descreve a variação da biomassa e necromassa aérea, e da produção primária líquida (NAGPP) de duas espécies invasoras Panicum maximum Jacquin (Poaceae) e Pteridium arachnoideum (Kaulf.) Maxon. (Dennstaedtiaceae) em duas áreas da Reserva Biológica de Poço das Antas, no sudeste brasileiro. As duas espécies eram mono-dominantes nestas áreas, ambas localizadas na matriz entre fragmentos florestais. A matéria orgânica foi amostrada mensalmente durante dois anos, separada em biomassa e necromassa e a produção aérea primária líquida (NAGPP) foi calculada. Houve variação intra-sazonal bem marcada, para ambas as espécies; Pa. maximum geralmente apresentou os maiores valores para biomassa, necromassa, massa total e NAGPP (NAGPP, Pa. maximum $=3953 \mathrm{~g} \mathrm{~m}^{-2}$ ano $^{-1}, P t$. arachnoideum $=2667 \mathrm{~g} \mathrm{~m}^{-2}$ ano $^{-1}$ ). A NAGPP não variou entre as duas estações de crescimento para $P$ a. maximum, porém estas diferenças foram acentuadas para Pt. arachnoideum (2\% comparados aos $44 \%$ de variação em relação a média). A segunda estação de crescimento foi mais seca e $\mathrm{Pa}$. maximum produziu maior quantidade de necromassa do que na primeira estação de crescimento; Pteridium mostrou pouca variação sazonal de biomassa, mas uma maior produtividade na segunda estação de crescimento. Pteridium arachnoideum é aparentemente mais sensível ao clima, especialmente em relação à pluviosidade.
\end{abstract}

Palavras-chave: fogo, Panicum maximum, plantas invasoras, Pteridium arachnoideum

ABSTRACT - (Variation in aboveground biomass and necromass of two invasive species in the Atlantic Rain Forest, Southeast Brazil). This paper describes the variation of the above-ground biomass, necromass, and net above-ground primary production (NAGPP) of two weed species, Panicum maximum Jacquin (Poaceae) and Pteridium arachnoideum (Kaulf.) Maxon. (Dennstaedtiaceae), at two sites in the Poço das Antas Biological Reserve, southeast Brazil. Both species form mono-dominant stands in the matrix surrounding forest fragments. The organic matter was sampled monthly from each site, separated into biomass and necromass, and net above-ground primary production (NAGPP) was calculated. There was marked intra-seasonal fluctuation for both species; Pa. maximum generally had the largest values for necromass, total mass and NAGPP(NAGPP, Pa. maximum $=3953 \mathrm{~g} \cdot \mathrm{m}^{-2} \cdot \mathrm{y}^{-1}$, Pt. arachnoideum $=2667 \mathrm{~g} \cdot \mathrm{m}^{-2} \cdot \mathrm{y}^{-1}$ ). NAGPP did not vary between the two growth periods for Pa. maximum, but marked differences were found for Pt. arachnoideum (2\% compared to $44 \%$ variation around the mean). The second growth year was drier and $P$ a. maximum produced much greater necromass in that year; Pt. arachnoideum showed little variation in biomass but much greater productivity in the drier second season. Pteridium arachnoideum appears to be more sensitive to climate, and especially rainfall.

Key words: fire, Panicum maximum, plant invasion, Pteridium arachnoideum

\section{Introduction}

The problem of invasive plant species has long been a focus of interest for ecologists (Elton 1958). More recently Mooney and Hobbs (2000) have described the artificial distribution of flora and fauna of the various continents as a "massive biotic homogenization of the Earth's surface". This has been brought about through anthropogenic factors and involves a combination of increased movement of species and changing of environmental conditions, including the disturbance regime, at local-, regional- and global scales that provide new opportunities for invasive species (IUCN 1999; Mooney \& Hobbs 2000). As a consequence, some of the more aggressive species are causing problems for conservation.

The Atlantic rainforest is an important ecosystem in Brazil due to its high biodiversity and number of

\footnotetext{
${ }^{1}$ Universidade Federal do Rio de Janeiro, Departamento de Ecologia, Centro de Ciências da Saúde, Ilha do Fundão, 21941-590 Rio de Janeiro, RJ, Brazil

2 Universidade Federal de São Carlos, Departamento de Botânica, C. Postal 676, Rod. Washington Luis km 235, 13565-905 São Carlos, SP, Brazil

3 University of Liverpool, Liverpool, L69 7ZB, UK

4 Corresponding author: dmatos@ufscar.br
} 
endemic species (Myers et al. 2000). This forest type originally occurred along the coastal area; presently its extent has been reduced to $8 \%$ of its original size (Myers et al. 2000). One of the perceived threats to the Atlantic rainforest is an increase in disturbance and a subsequent increase in invasive species. Prescibed fire has recently become very frequent in the Atlantic forest linked to agriculture and pasture. Many large mature forests have been reduced to small fragments surrounded by early successional vegetation which is managed by fire (Uhl et al. 1990; Silva Matos et al. 2005), and forest regeneration is prevented (Whelan 1995 for review). One of the major factors that determines the impact of fire is the fuel load that is related to biomass accumulation (biomass and necromass); this affects the likelihood, intensity and rate of spread of the fire (Whelan 1995), and rate of post-fire vegetation recovery. Although biomass is important in determining fire characteristics and impact, this is rarely quantified (Whelan 1995).

In southeast Brazil, the ecosystems that develop between remnant forest fragments, i.e. in abandoned pastures, around forest edges and in other degraded areas are often dominated by productive grasses and ferns, and some of these species are invading the Atlantic Forest (Silva Matos et al. 2002, Silva \& Silva Matos 2006). Two species that are present in abundance in such situations are the grass Panicum maximum Jacquin (Poaceae) (Guinea Grass) and the fern Pteridium arachnoideum (Kaulf.) Maxon. (Dennstaedtiaceae) (Bracken). Both species are widely known for their competitive ability and high production of biomass (Chou \& Young 1975; Marrs et al. 1998a), and this biomass could act as a large fuel load (Hughes et al. 1991; D'Antonio \& Vitousek 1992; Plat \& Gottscahlk 2001). Unfortunately almost nothing is known about the biology of these two species in the Atlantic forest.

The aim of this study was to investigate the variation of biomass, necromass and net primary production of $P a$. maximum and Pt. arachnoideum over two years to provide baseline information on potential fuel loads. A secondary aim was to relate these mass variables to seasonal variation in rainfall and temperature. We expect higher biomass production during the rainy season while necromass is expected to be higher in the dry season.

\section{Material and methods}

Study species - Panicum maximum is an African species that has been introduced to almost all tropical countries as a source of animal forage (D'Antonio \& Vitousek 1992; Relling et al. 2001). This species grows well on a wide variety of soils and is drought resistant (Naturia 2002). Under drought conditions there is often an accumulation of biomass that acts as large fuel load, so that when a fire occurs, the burn temperatures are extremely high and regeneration of fire-intolerant native plants does not occur (Naturia 2002). Panicum maximum dominates the vegetation after fire; this domination is possibly assisted by strong allelopathic activity and fire tolerance (Chou \& Young 1975). Panicum maximum also produces dense root mats; it is often planted to stop soil erosion on slopes in southeast Brazil, including the Atlantic forests. Moreover, it occurs along roadsides, on disturbed sites and gradually extends into undisturbed forests (Silva Matos et al. 2002).

Pteridium arachnoideum is a worldwide weed (Marrs \& Watt 2006). It usually has a large biomass of underground fire-tolerant rhizomes that store carbohydrates and contain a large number of dormant buds (Marrs et al. 1998a; Johnson 2001). It has been considered a typical aggressive, inflammable pioneer species that occurs in burnt or deforested sites (AlonsoAmelot \& Rodulfo-Baechler 1996; Humphey \& Swaine 1997; Skre et al. 1998; Johnson 2001).

Study site - The site was located in the Poço das Antas Biological Reserve (ReBio) $\left(22^{\circ} 30^{\prime}-22^{\circ} 33^{\prime} \mathrm{S}, 4^{\circ} 15^{\prime}\right.$ $42^{\circ} 19^{\prime} \mathrm{W}$ ), in Silva Jardim county, Rio de Janeiro, southeast Brazil. The ReBio (5000 ha) (IBAMA 1989) is one of the few remnants of Atlantic forest in Rio de Janeiro, comprising a central core of typical lowland coastal forest at different successional stages surrounded by dense stands of invasive species (Silva Matos et al. 2005).

The maximum elevation is $205 \mathrm{~m}$ and climate is Equatorial (Walter 1971). Mean annual rainfall was $2092 \mathrm{~mm}$ from 1987 to 1997 . There are seasonal fluctuations in rainfall with a drier period from May to August and a rainy season from September to April (Fig. 1). Mean monthly temperature $\left({ }^{\circ} \mathrm{C}\right)$ and rainfall $(\mathrm{mm})$ were obtained from Programa Mata Atlântica Project from the Jardim Botânico do Rio de Janeiro, about $20 \mathrm{~km}$ from the study site.

Two study plots of $10 \times 15 \mathrm{~m}$ within areas dominated by either Pa. maximum or Pt. arachnoideum were marked out in the matrix surrounding forest fragments known locally as Arquipélago dos Barbados (Souza \& Martins 2002). The soils of these plots have an organic layer and are best described as peats. The study site was a wetland, but it has become drier and susceptible to fires after a dam was constructed in 1983. Succession has been arrested by fire in these plots with the subsequent creation of mono-dominant stands of either Pa. maximum or Pt. Arachnoideum (Silva Matos et al. 2005). 

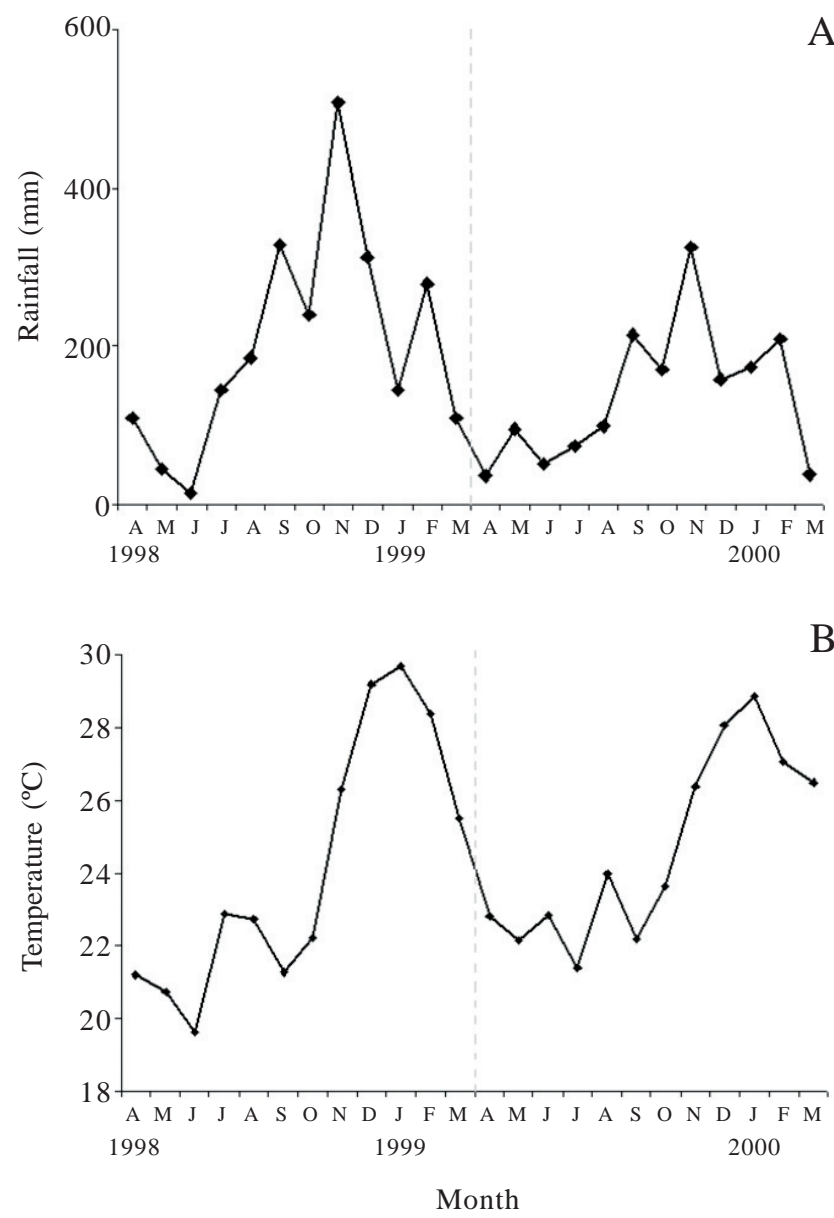

Figure 1. Monthly (A) rainfall $(\mathrm{mm})$ and $(\mathrm{B})$ temperatures $\left({ }^{\circ} \mathrm{C}\right)$ from April 1998 to March 2000 in the Atlantic rainforest, Southeast Brazil.

Experimental design - Biomass and necromass $\left(\mathrm{g} \mathrm{m}^{-2}\right)$ were sampled using three samples in each study plot over two study years, i.e. two complete growing cycles of each species starting in May 1998 and finishing in April 2000. For each sample a $0.25 \mathrm{~m}^{2}$ area was located randomly in each study plot without resampling (Ovington 1963), and the above-ground organic vegetation harvested. These samples were then taken to the laboratory where the harvested material was sorted into dead organic material, having no visible chlorophyll (necromass) and living material (biomass). After separation, the samples were dried at $80{ }^{\circ} \mathrm{C}$ to constant weight (Ovington 1963; Gaona et al.1996). There was no replication of the two treatment plots, so it is impossible go ascribe observed differences to treatments.

The above-ground biomass and necromass were plotted temporally; mean values for each season and overall mean were calculated using $\log _{\mathrm{e}}$ transformed data to normalize them and homogenize the variances. Differences on the above-ground biomass and necromass between species were compared using a 2-tailed t-test
(Crawley 2007). Net above-ground primary production (NAGPP, $\mathrm{g} \mathrm{m}^{-2} \mathrm{y}^{-1}$ ) was calculated using Smalley's (1958) method as recommended by Linthurst and Reimold (1978) and Gaona et al. (1996). This method estimates NAGPP by summing the differences between each successive sampling time using both dry matter of above-ground biomass (B) and necromass $(\mathrm{N})$ and four rules: (1) If $\mathrm{B}$ and $\mathrm{N}$ both increase then NAGPP $=\mathrm{B}+$ $\mathrm{N}$; (2) If both $\mathrm{B}$ and $\mathrm{N}$ decrease then NAGPP $=0$; (3) If $\mathrm{B}$ increases and $\mathrm{N}$ decreases, then NAGPP $=\mathrm{B}$; and (4) If $\mathrm{N}$ increases and $\mathrm{B}$ decreases then $\mathrm{T}=\mathrm{B}+\mathrm{N}$, and if $\mathrm{T} \leq 0$ then NAGPP $=0$, or $\mathrm{T}>0$ then $\mathrm{NAGPP}=\mathrm{T}$.

Although Smalley's method is very simple, it takes account, albeit crudely, of both production and death of the plant material, to some extent overcoming Bradbury and Hofstra's (1976) criticism that NPP is usually overestimated because often no estimate of loss of green material is considered.

The temporal relationships between (1) biomass and necromass for each species, and (2) biomass, necromass and total organic material versus both rainfall and temperature were assessed using simple time series analysis, where correlation coefficients (Pearson) were calculated between the raw data and at monthly lagged intervals up to lag $=5$ (see Crawley 2002). Regression models using general linear models were fitted between biomass data $\left(\log _{\mathrm{e}}\right.$ transformed) and both rainfall and temperature. Significance was assessed using the AIC statistic and the reduction in deviance. All statistical analyses were performed using the $\mathrm{R}$ statistical package (www.cran.r-project.org/).

\section{Results}

There was a pronounced cyclic pattern in rainfall and temperature reflecting the dry and wet seasons over the two study years (Fig. 1). In each year the wettest period occurred between January and March, the coolest months were between May and August and the warmest month was December. Mean monthly temperatures were very similar between the two study years but the rainfall was greater and had a greater monthly variability in the first than in the second year (Tab. 1).

There were marked within-year variations for biomass and necromass for both species (Fig. 2). However, for Pa. maximum there was little difference in biomass values between years, but there was a significant increase in necromass in the second year, which was drier. For Pt. arachnoideum there were no obvious temporal differences although the necromass was usually greater than the biomass.

The total organic matter of $P a$. maximum was significantly greater than that of Pt. arachnoideum over 
the 24 months; however, this masked differences between the two study years, with no significant difference in year 1 but a highly significant difference in year 2. There was no significant difference in biomass throughout the study, and all differences were found in

Table 1. Mean $( \pm \mathrm{SE})$ monthly temperature $\left({ }^{\circ} \mathrm{C}\right)$ and rainfall $(\mathrm{mm})$ over the two years from April 1998 to March 2000 in the Atlantic rainforest.

\begin{tabular}{lccc}
\hline Variable & $\begin{array}{c}\text { Over both Years } \\
(\mathrm{n}=24)\end{array}$ & $\begin{array}{c}\text { Year 1 } \\
\text { Months } \\
1-12 \\
(\mathrm{n}=12)\end{array}$ & $\begin{array}{c}\text { Year 2 } \\
\text { Months } \\
13-24 \\
(\mathrm{n}=12)\end{array}$ \\
\hline $\begin{array}{c}\text { Mean monthly } \\
\text { temperature }\end{array}$ & $24 \pm 0.6$ & $24 \pm 1.0$ & $25 \pm 0.7$ \\
$\begin{array}{c}\text { Mean monthly } \\
\text { rainfall }\end{array}$ & $169 \pm 24.2$ & $202 \pm 40.2$ & $137 \pm 25.2$ \\
\hline
\end{tabular}
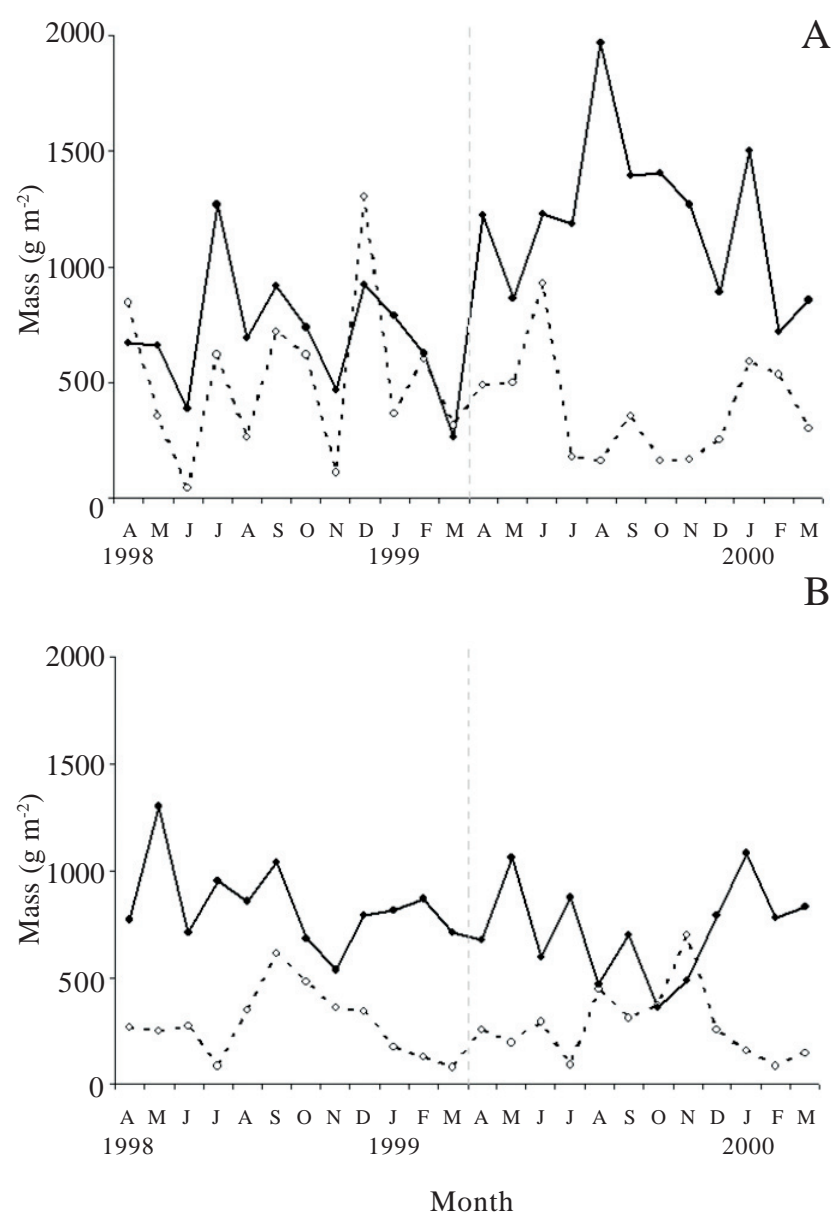

Figure 2. Change in biomass $(\mathrm{o}=$ dashed $)$ and necromass $(\bullet=$ solid $)$ (g.m ${ }^{-2}$ ) from April 1998 to March 2000 of (A) Panicum maximum (Poaceae) and (B) Pteridium arachnoideum (Dennstaedtiaceae) invading an area of Atlantic forest in the Poço das Antas National Biological Reserve, Southeast Brazil; mean values $(n=3)$ are presented. the necromass component (Tab. 2). Panicum maximum had almost double the necromass of Pt. arachnoideum in the second season.

The NAGPP estimated over the 24 months for $P a$. maximum was $3953 \mathrm{~g} \cdot \mathrm{m}^{-2} \cdot \mathrm{yr}^{-1}$, with little difference between the two years (year $1=4033 \mathrm{~g} \mathrm{~m}^{-2} \mathrm{yr}^{-1}$ and year $2=3874 \mathrm{~g} \mathrm{~m}^{-2} \mathrm{yr}^{-1}$ ), both within $2 \%$ of the overall mean. The value for $P$ a. maximum was $32 \%$ higher than for Pt. arachnoideum, which had a mean of $2667 \mathrm{~g} \mathrm{~m}^{-2} \mathrm{yr}^{-1}$. Moreover, there was a greater variability for Pt. arachnoideum with a value of $1475 \mathrm{~g} \mathrm{~m}^{-2} \mathrm{yr}^{-1}$ for year 1 compared to $3859 \mathrm{~g} \mathrm{~m}^{-2} \mathrm{yr}^{-1}$ for year 2 ; a $44 \%$ variation around the overall mean.

For Pa. maximum there was only a single significant negative correlation between necromass and rainfall, after a lag of three months, suggesting that necromass increases in an extended period of low rainfall, this is in keeping with the high necromass results during the second drier season (Tab. 3). On the other hand, Pt. arachnoideum showed a significant correlation between biomass and necromass at a lag of four months, and significant correlations between rainfall (at lags of 0 (+ve), 3 (-ve), 4 (-ve) and 5 (-ve) months) and temperature (at lags of 1, 2, 3 and 4 months (all -ve)) (Table 3). For Pa. maximum no significant relationship between temperature and rainfall was found by $\mathrm{glm}$ modelling in terms of reduction in the AIC statistic, but for Pt. arachnoideum significant relationships were found between biomass and rainfall (singly and in combination with temperature) with reductions in both the AIC statistic and deviance (null model, AIC $=48.2$, Deviance $=8.84 ;+$ temperature, $\mathrm{AIC}=48.2$, Deviance $=8.46 ;$ +rainfall, $\mathrm{AIC}=46.7$, Deviance $=7.65 ;$ +rainfall+temperature, AIC $=44.3$, Deviance $=6.38$ ).

\section{Discussion}

This study described the biomass and above-ground productivity of two weeds ( $P a$. maximum and $P t$. arachnoideum) that invaded and formed mono-dominant stands between fragments of Atlantic Rain Forest in southeast Brazil. The above-ground necromass and total organic matter of $P a$. maximum was usually greater than Pt. arachnoideum. The mean biomass measured here (Pa. maximum $=349 \mathrm{~g} \mathrm{~m}^{-2} ;$ Pt. arachnoideum $\left.=236 \mathrm{~g} \mathrm{~m}^{-2}\right)$ compared favourably with ranges measured elsewhere (Pa. maximum 337-430 $\mathrm{g} \mathrm{m}^{-2}$ from Mexico, Kenya and Thailand, Long et al. (1989); Pt. arachnoideum 170-1408 $\mathrm{g} \mathrm{m}^{-2}$ from the UK (Marrs \& Watt 2006), and 45-1461 $\mathrm{g} \mathrm{m}^{-2}$ from New Zealand (Bray 1991). The Pt. arachnoideum values are, however, smaller than the $1300 \mathrm{~g} \mathrm{~m}^{-2}$ measured for frond biomass in Venezuela (Alonso-Amelot \& Rodulfo-Baechler 1996). 
Table 2. Above-ground biomass, necromass and total organic material of Panicum maximum Jacquin (Poaceae) and Pteridium arachnoideum (Kaulf.) Maxon. (Dennstaedtiaceae) invading an Atlantic forest in the Poço das Antas National Biological Reserve, Southeast Brazil, over two study years between April 1998 and March 2000. Means \pm SE of $\log _{\mathrm{e}}$ transformed data are presented along with t-values of significance (2-tailed) between $\mathrm{Pa}$. maximum and Pt. arachnoideum; back-transformations of the geometric means are presented in bold to provide an estimate of actual measurements $\left(\mathrm{g} \mathrm{m}^{-2}\right)$. $(\mathrm{ns})=$ not significant, $(*)=\mathrm{P} \leq 0.05,(* * *)=\mathrm{P} \leq 0.001$.

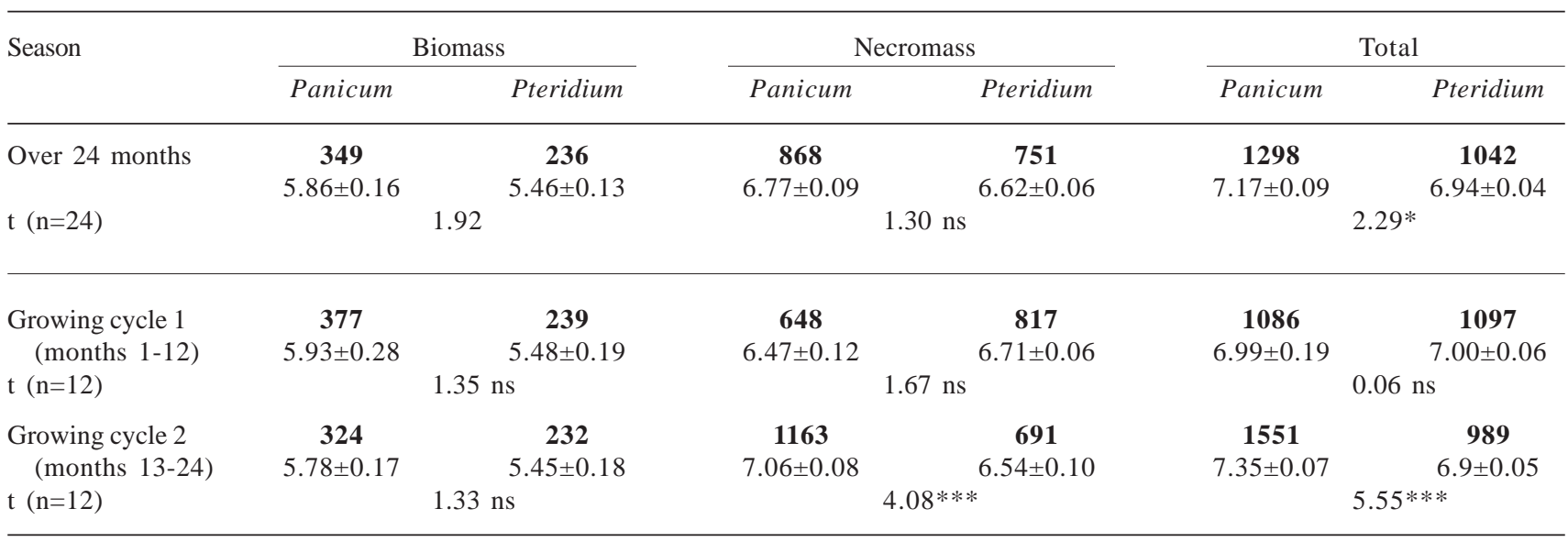

Table 3. Pearson correlation coefficients calculated between five pairs of variables at lagged intervals from 0 up to 5 months for Panicum maximum Jacquin (Poaceae) and Pteridium arachnoideum (Kaulf.) Maxon. (Dennstaedtiaceae) invading an Atlantic forest in the Poço das Antas National Biological Reserve, Southeast Brazil over two study years (1998-2000). Correlations in bold are significant, $(*)=\mathrm{P}<0.05$; $(* *)=\mathrm{P}<0.01$.

\begin{tabular}{|c|c|c|c|c|c|c|c|c|c|c|c|c|}
\hline \multirow[t]{2}{*}{ Variables correlated } & \multicolumn{6}{|c|}{ Panicum maximum } & \multicolumn{6}{|c|}{ Pteridium arachnoideum } \\
\hline & $\mathrm{Lag}=0$ & $\mathrm{Lag}=1$ & $\mathrm{Lag}=2$ & Lag $=3$ & $\mathrm{Lag}=4$ & $\mathrm{Lag}=5$ & $\mathrm{Lag}=0$ & $\mathrm{Lag}=1$ & $\mathrm{Lag}=2$ & $\mathrm{Lag}=3$ & $\mathrm{Lag}=4$ & $\mathrm{Lag}=5$ \\
\hline iomass vs. Necromass & -0.001 & -0.360 & -0.167 & -0.359 & -0.321 & 7 & 74 & -0.163 & -0.170 & 0.201 & $0.520 *$ & 0.158 \\
\hline Biomass vs. Rainfall & 0.112 & 0.363 & 0.080 & 0.307 & 0.144 & 0.121 & $0.458 *$ & 0.173 & -0.088 & $-0.459 *$ & $-0.635 * *$ & $-0.523 *$ \\
\hline Biomass vs. Temperature & 0.145 & 0.183 & 0.074 & -0.026 & 0.055 & 0.126 & -0.181 & $-0.425 \%$ & $-0.488 *$ & $-0.441 *$ & $-0.475 *$ & -0.248 \\
\hline Necromass vs. Rainfall & -0.120 & -0.292 & -0.241 & $-0.525 *$ & -0.422 & -0.146 & -0.203 & -0.168 & 0.104 & 0.187 & 0.158 & 0.301 \\
\hline Necromass vs. Temperature & 0.008 & -0.220 & -0.207 & -0.270 & -0.006 & 0.418 & -0.100 & 0.103 & 0.167 & 0.039 & 0.072 & 0.145 \\
\hline
\end{tabular}

Productivity values are more difficult to relate to literature values because of methodological issues. The NAGPP of $3953 \mathrm{~g} \mathrm{~m}^{-2} \mathrm{yr}^{-1}$ for $P a$. maximum is lower than the $6300 \mathrm{~g} \mathrm{~m}^{-2} \mathrm{yr}^{-1}$ obtained from grassland near Manaus in Brazil (Long et al. 1989). Few productivity estimates have been made for Pt. arachnoideum because measurements are complicated by transfer to, and from, the rhizome system (Marrs \& Watt 2006). The NAGPP estimate for Pt. arachnoideum of $2667 \mathrm{~g} \mathrm{~m}^{-2} \mathrm{yr}^{-1}$ is greater than the maximum UK estimate of $2100 \mathrm{~g} \mathrm{~m}^{-2} \mathrm{yr}^{-}$ ${ }^{1}$, which rhizome production (Marrs \& Watt 2006). This implies that Pt. arachnoideum production in seasonal tropical conditions is high.

Perhaps the most interesting result was the very marked difference between the two species over the two years. $P a$. maximum showed similar productivity in both years but much greater necromass in the drier, second year, implying that the flux from biomass to necromass increases in dry conditions. In contrast Pt. arachnoideum showed a very large difference in productivity between years, with the drier year being $30 \%$ greater than the wetter one.

The correlations between biomass/necromass and climate variables supported these conclusions. For $P a$. maximum, there was only a single significant negative relationship found between necromass and the rainfall falling three months earlier; suggesting that when a wet period is followed by an especially dry period, as occurred in year 2, there is increased necromass production. For Pt. arachnoideum, relationships with rainfall and temperature were more complex. Rainfall appeared to be more important than temperature: for rainfall there was an overall positive relationship but negative lag effects were also detected. These results suggest that biomass was lower in the drier season reflecting the reduced productivity in the second season. For temperature, negative effects were found at 2-4 monthly lags suggesting that bracken productivity is reduced by high temperatures.

The present data are a first measure of biomass 
and productivity of these species in the Atlantic forests. This study needs to be repeated because our results come from single stands. The potential relationship with rainfall is certainly worth exploiting further; in similar singlesite studies no significant relationship was found between Pt. arachnoideum biomass and precipitation in the UK (Marrs et al. 1998b). It is possible that the very pronounced fluctuations in annual rainfall in tropical conditions are critical in explaining these apparent differences.

From a resource management viewpoint the fact that both species form a dense canopy and litter cover throughout the year indicates that invasion by both species results in a permanent high fire risk, especially in the drier year when necromass increased. Moreover, as the organic matter for both species is concentrated near the ground level, we might expect that high fire temperatures near the soil surface will negatively affect seedling regeneration or it will cause local extinctions of native species (D'Antonio \& Vitousek 1992; Skre et al. 1998; Johnson, 2001; Plat \& Gottscahlk 2001). Once dense stands of Pa. maximum and Pt. arachnoideum are established they are also likely to suppress seedling establishment through direct competition and through the production of dense litter (Watt 1940; Bray 1991; Marrs et al. 1998a).

Thus, as fire and other deforestation process continue to occur in the Poço das Antas Biological Reserve and elsewhere in Brazil, Pa. maximum and Pt. arachnoideum are predicted to expand quickly in forest fragments. Positive management of both species is advised to stop further expansion into natural reserves. Fortunately, Pa. maximum can be controlled by mowing (Ezequiel \& Favoretto 2000), but information on Pt. arachnoideum control is lacking for South America. Replicated, multi-site experiments to test and develop methods of control for both species are sorely needed (e.g. Le Duc et al. 2000).

\section{Acknowledgements}

We thank the Conselho Nacional de Desenvolvimento Científico e Tecnológico (CNPq), Fundação de Amparo a Pesquisa do Estado do Rio de Janeiro (FAPERJ), Fundação O Boticário de Proteção a Natureza and Fundação de Amparo a Pesquisa do Estado de São Paulo (FAPESP) for financial support. We also thank Instituto Brasileiro do Meio Ambiente e Recursos Naturais Renováveis (IBAMA) for research permission, Paula Lira and Eraldo for field assistance, and Vânia Pivello and Michael D. Swaine for helpful comments on an early draft of this manuscript.

\section{References}

Alonso-Amelot, M.E. \& Rodulfo-Baechler, S. 1996. Comparative spatial distribution, size, biomass and growth rate of two varieties of bracken fern (Pteridium aquilinum L.Kuhn) in a neotropical montane habitat. Vegetatio 125: 137-147.

Bradbury, I.K. \& Hofstra, G. 1976. Vegetation death and its importance in primary production measurements. Ecology 57: 209-211.

Bray, R.J. 1991. Growth, biomass, and productivity of a bracken (Pteridium esculentum) infested pasture in Marlborough Sounds, New Zealand. New Zealand Journal of Botany 29: 169-176.

Chou, C.H. \& Young, C.C. 1975. Phytotoxic substances in twelve subtropical grasses. Journal of Chemistry Ecology 1: 183-193.

Crawley, M.J. 2002. Statistical computing: an introduction to data analysis in S-Plus. John Wiley, Chichester.

Crawley, M.J. 2007. The R book. John Wiley, Chichester.

D'Antonio, C.M. \& Vitousek, P.M. 1992. Biological invasions by exotic grasses, the grass/fire cycle, and global change. Annual Review of Ecology and Systematic 23: 63-87.

Elton, C.S. 1958. The ecology of invasions by animals and plants. Univ. of. Chicago Press, Chicago.

Ezequiel, J.M. \& V. Favoretto. 2000. Efeito do manejo sobre a produção e composição química de perfilhos do capim-colonião (Panicum maximum Jacq.). Revista Brasileira de Zootecnia 29: 1596-1607.

Gaona, C.A.P.; Peixoto, A.R. \& Costa, C.S.B. 1996. Produção primária de uma marisma raramente alagada dominada por Juncus effusus L., no extremo Sul do Brasil. Atlântica 18: 43-54.

Hughes, F.; Vitousek, P.M. \& Tunison, T. 1991. Alien grass invasion and fire in the seasonal submontane zone of Hawaii. Ecology 72: 743-746.

Humphey, J.W. \& Swaine, M.P. 1997. Factors affecting the natural regeneration of Quercus in Scottish oakwoods. I Competition from Pteridium aquilinum. Journal Applied Ecology 34: 577-584.

IBAMA 1989. Unidades de conservação do Brasil. v.1. Parques Nacionais e Reservas Biológicas. Brasília, Brazil.

IUCN [International Union for the Conservation of Nature]. 1999. IUCN guidelines for the prevention of biodiversity loss due to biological invasion. Species 31/32: 28-42.

Johnson, P.N. 2001. Vegetation recovery after fire on a southern New Zealand peatland. New Zealand Journal of Botany 39: 251-267.

Le Duc, M.G.; Pakeman, R.J.; Putwain, P.D. \& Marrs R.H. 2000. The variable responses of bracken fronds to control treatments in Great Britain. Annals of Botany 85B: 17-29.

Linthurst, R.A. \& Reimold, R.J. 1978. An evaluation of methods for estimating the net aerial primary productivity of estuarine angiosperms. Journal of Applied Ecology 15: 919-931.

Long, S.P.; Garcia Moya, E.; Imbamba, S.K.; Kamnalrut, A.; Piedade, M.T.F.; Scurlock, J.M.O.; Shen, Y.K. \& Hall, D.O. 1989. Primary productivity of natural grass ecosystems of the tropics: a reappraisal. Plant and Soil 115: 155-166.

Marrs, R.H. \& Watt A.S. 2006. Biological flora of the British Isles: Pteridium aquilinum (L.) Kuhn. Journal of Ecology 94: 12721321.

Marrs, R.H.; Johnson, S.W. \& Le Duc, M.G. 1998a. Control of bracken and restoration of heathland. VII. The response of bracken rhizomes to 18 years of continued bracken control or 6 years of control followed by recovery. Journal of Applied Ecology 35: 748-757. 
Marrs, R.H.; Johnson, S.W. \& Le Duc, M.G. 1998b. Control of bracken and restoration of heathland. VI. The response of bracken fronds to 18 years of continued bracken control or 6 years of control followed by recovery. Journal of Applied Ecology 35: 479-490.

Mooney, H.A. \& Hobbs, R.J. 2000. Invasive species in a changing world. Washington, Island Press.

Myers, N.; Mittermeier, R.A.; Mittermeier, C.G.; Fonseca, G.A. \& Kent, J. 2000. Biodiversity hotspots for conservation priorities. Nature 403: 853-858.

Naturia. 2002. Mangrove and wetland wildlife at Sungei Buloh Nature Park. www.naturia.per.sg/buloh/plants/ guinea_grass.htm.

Ovington, J.D. 1963. Plant biomass and productivity of prairie, savanna, oakwood, and maize field ecosystems in central Minnesota. Ecology 44: 52-63.

Plat, W.J. \& Gottschalk, R.M. 2001. Effects of exotic grasses on potential fine fuel loads in the groundcover of south Florida slash pine savannas. International Journal of Wildland Fire 10: 155-159.

Relling, E.A.; van Niekerk, W.A.; Coertze, R.J. \& Rethman, N.F.G. 2001. An evaluation of Panicum maximum cv. Gatton: 1 . The effect of stocking rate and period of absence on the production of sheep. South African Journal of Animal Science 31: 77-83.

Skre, O.; Wielgolaski, F.E. \& Moe, B. 1998. Biomass and chemical composition of common forest plants in reponse to fire in western Norway. Journal of vegetation Science 9: $501-510$
Smalley, A.E. 1958. The role of two invertebrate populations, Littorina irrorata and Orchelimum fidicinum in the energy flow of a salt marsh ecosystem. (Dissertation, Univ. of Georgia, Athens). In: C.A.P. Gaona; A.R. Peixoto \& C.S.B. Costa 1996. Produção primária de uma marisma raramente alagada dominada por Juncus effusus L., no extremo Sul do Brasil. Atlântica 18: 43-54

Silva, U.S.R. \& Silva Matos, D.M. 2006. The invasion of Pteridium aquilinum and the impoverishment of the seed bank in fire prone areas of Brazilian Atlantic Forest. Biodiversity and Conservation 15: 3035-3043.

Silva Matos, D. M.; Fonseca, G.D.F.M. \& Lima, L.S. 2005. Differences on post-fire regeneration of the pioneers Cecropia glazioui and Trema micrantha in a lowland Brazilian Atlantic Forest. Revista de Biología Tropical 53: 1-4.

Silva Matos, D.M.; Santos, C.J. \& Chevalier, D.R. 2002. Fire and restoration of the largest urban forest of the world in Rio de Janeiro City, Brazil. Urban Ecosystem 6: 151-161.

Souza, A.F. \& Martins, F.R. 2002. Spatial distribution of an undergrowth palm in fragments of the Brazilian Atlantic Forest. Plant Ecology 164: 141-155.

Uhl, C.; Kauffman, J.B. \& Silva, E.D. 1990. Os caminhos do fogo na Amazônia. Ciência Hoje 11: 25-32.

Walter, H. 1971. Ecology of tropical and subtropical vegetation. Edinburgh, Oliver \& Boyd.

Watt, A.S. 1940. Contributions to the ecology of bracken (Pteridium aquilinum). I.The rhizome. New Phytologist 39: 401-411.

Whelan, R.J. 1995. The ecology of fire. Cambridge, Cambridge University Press. 